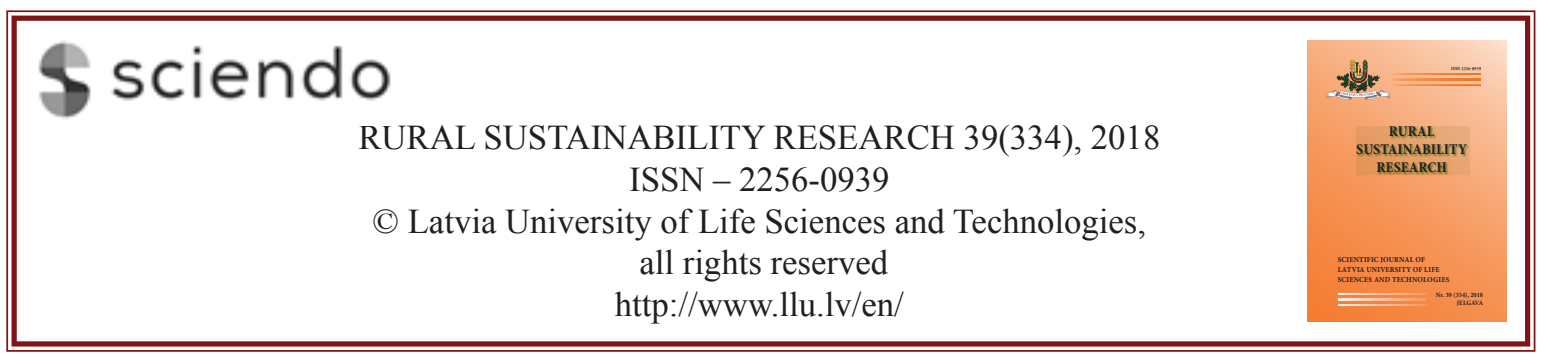

\title{
Cassava Productivity for Eradicating Hunger and Poverty in Rural Areas of Indonesia
}

\author{
*Yudi Widodo \\ Senior Agronomist Indonesian Legume and Tuber Crops Research Institute (ILETRI) \\ Jl Raya Kendalpayak km 8, P.O. Box 66 Malang 65101, Indonesia
}

\begin{abstract}
Population of Indonesian around 265,015,300 people, so they need a huge amount of food. Rice is the most important food staple, but it is still imported around 500,000 $\mathrm{t}$ to stabilize the price in Indonesia. However, the country's import of wheat is approximately $>10,000,000$ t. Hunger reduction and poverty eradication are the top priorities under SDGs (Sustainable Development Goals). Production of food based on cereals and grains was inert. Thus to meet the global claims root-crops, particularly cassava, has the potential to be explored. Cassava originated from tropical Latin America; it was distributed to Asia and Africa after Columbus discovered America in the $15^{\text {th }}$ century. Early distribution of cassava was only across the longitude, recently its distribution is athwart the latitude. Literature review as well as arena reflection were used to gather information to meet the methodology in this research. Increasing productivity to meet the demand of food, feed, and other industrial needs with prosperous communities is considered an endless charity which requires a solid global cooperation. Price fluctuation was a factor affecting cassava progress; however, it was neglected by the government.
\end{abstract}

Keywords: cassava, poverty alleviation, hunger reduction.

\section{Introduction}

Food is not everything, but without food human can do nothing. Civilization of human was impeded by serious food scarcity. Therefore, to create better future civilization, among eight objectives listed in Sustainable Development Goals (SDGs), reduction of hunger as well as alleviation of poverty is the first rank plus top priority. FAO (2017) predicts that around 1 billion people are undernourished all over the world distributed in 34 countries. FAO (2017) also points out that global food stock cereal base under crisis and to increase food production is much more difficult due to severe weather shocks caused by climate change; therefore, the richness of biodiversity should be maintained and utilized optimally. Ohlhorst et. al. (2012) worried about the budget limitation to attain food production as recommended by sustainable agriculture in order to fulfill the food for current generation without conflicting with the need of food for the future generation. However, the implementation of sustainability is still very poor and remains debatable. Starting from the concepts of food sufficiency up to security, and then food sovereignty were defined, but to meet food demand, cereal and grain crop commodities merely more dominate. The natural root and tuber crops, which the main yield is underground and consider dirty, therefore cereal and grain mentality neglecting the role of root and tuber crops. Indeed root and tuber crops were the main food source during the ancient civilization. Unfortunately, the modern life style prefers cereal and grain whose yield is located above the ground and easy to harvest and maintain. Better awareness of community about food scarcity based on cereal and grain forces to find alternatives by reinventing the potential of root and tuber crops. Unlike cereal and grain, the attention to root and tuber crops, including cassava from research to production and utilization is not proportional and is considered low. According to Veltkamp and de Bruijn (1996), cassava has a wide adaptability to tropical areas from upland dry areas to wet climate zone.

\section{Materials and Methods}

The aim was to draw up the potential of cassava in

\footnotetext{
* Corresponding Author's email:

yudi_atas@yahoo.com
}

DOI:10.2478/plua-2018-0005 
Indonesia by using several methods such as a policy of cassava for rural development in a form of desk study. Data were collected from FAO, CIAT as well as Statistic of Indonesia on agricultural food crops production. To provide adequate information about the potential of cassava for hunger reduction and poverty, alleviation was done by inductive and deductive approaches which are executed simultaneously into convergence parity. Descriptive research method is also employed for accomplishing better finding. Eligible references related to cassava development were collected and understood clearly. References accessed from library as well as on line are executed in this study. Illegible and ambiguous information were evaluated further into detail primary as well as secondary data collected from Ministry of Agriculture, Ministry of Forestry and Indonesia Statistical Agency as well as from Food and Agriculture Organization (FAO) of United Nations (UN) and other international institutions under CGIAR such as Centro Internacional Agricultura Tropical (CIAT) Cali Columbia, International Institute for Tropical Agriculture (IITA) Ibadan Nigeria, Centre International Forestry Research (CIFOR) and International Centre Research for Agro-forestry (ICRAF) Bogor Indonesia. Intensive communications with the other authors' national, regional and international levels were actively built in order to clarify proper information through conferences, seminars and workshops as well as discussion via electronic mail (email) in the related field. To describe the fact and phenomena the observational method, field survey as well as in depth case study methods were adopted in order to obtain a better description (including prediction and explanation). Field survey was conducted by multiple visits. A series of multiple visits to cassava niche in the agro-forestry under areas of Perhutani (Forest State Enterprise) at Banten, West Java, Central Java and East Java as well as under forest managed by local communities in Sumatra, Kalimantan, Sulawesi, Nusatenggara till Papua were undertaken from 1995 to 2012. Starting from 2016 to 2020 the author was involved in the project of cassava value chain management by ACIAR (Australian Centre for International Agricultural Research).

\section{Results and Discussions}

\section{Lesson Learned from Indonesia}

Experience of Indonesia as the largest archipelago country to nourish the population around 265,015,300 people can be extrapolated to increase production of food not only for own dweller, but also for the global community which requires more food (Table 1). The concept of food security (Simatupang \& Fleming, 2001) was not differentiating the source of food (carbohydrate). As the major staple food is rice, food program merely focused on rice. In the beginning of crisis in 1997/98 World Food Program provided food aid in the form of rice. This program was in line with social safety net and afterwards it was followed by the rice for poor people (Sawit, 2002). In this program, every household was provided with $20 \mathrm{~kg}$ of rice with the price that was only $50 \%$ from the public market. The food aid program was also purchased for poor people who as workers were involved in the improvement of public facilities such as irrigation canals, village roads, etc. The philosophy behind the distribution of food aid under philanthropic program was properly designed that there was no free meal. Thus, to appreciate food, the poor must pay a low price or barter with their hard work (manual labor). Unfortunately, in order to provide the huge demand of rice the government tended to import it from outside. Consequently, the market and price of rice produced by farmers in the country was facing a difficult challenge (Saifullah, 2002). The worse of rice based on food system particularly from farmers as a producer side, affected the food crops other than rice, especially root-crops that were stagnant and tended to diminish. As the end result of the government support to provide rice that is easily available everywhere at any time in the country, food crops other than rice, root-crops in particular, were virtually neglected. This fact strongly affected the alteration of food pattern away from root-crops and tended to choose rice. This was a significant example of the weakness of food security based on market liberalization. In order to improve the food accessibility for poor people, the government provides subsidy, but on the other hand, protection of poor farmers who produced food was becoming fragile. Thus, very relevant question then came up whom the government of the country is for? Whom does the government stand for, for poor or for capitalism that is exploiting or conserving the poor as victims for growth and development. The structural change issued by reformation after almost 20 years was not able to alleviate poverty significantly, because it was not in line with cultural wisdom. Farmers as the major elector were as a tool or object to attain the power in the solid structure in the name of nation in a form of the government. Farmers had never been as the subject to decide by their sovereignty to attain better living and escape from poverty. Among 27 million poor people, around 50\% are root-crop farmers that live in an undulating upland. Cassava farmers marginalized and suffered more due to liberalization of agricultural market. Under poverty social imperative could not be attained, due to people there was a constant concern for fulfilling their basic daily needs. Consequently, social friction is easily transpired under poverty situation. 
Cassava a Major Rootcrops

Among the food crops in terms of harvest area, cassava is the third rank after rice and maize. However, from production performance, cassava is the second important source of carbohydrate after rice. Indeed the advantage of cassava as the source of food in terms of productivity is the best among tropical food crops (Table 2). Unfortunately, cassava is not received by the government of Indonesia as a priority compared to other food crops especially cereals and legumes, such as rice, maize and soybean. Under the program of food security attaining self sufficiency of pajale (rice=padi, maize=jagung, and soybean=kedele) have to be realized in 2018. Meanwhile, the recent trend indicates that there is an increase of demand for cassava especially for food related industries. According to Widodo (2011), the production of food from Java of that area only $7 \%$ with the population around $60 \%$ was able to contribute dominantly to the whole Indonesia. Unfortunately, the sustainability of agriculture in Java is a serious question to meet the greater future demand. Although agro-forestry production of food was widely applied by farmers in Java with intensive labor and inputs, detrimental effect to shoddier of the environment is obvious suffering by the dweller. Ecological catastrophes are flooding during the rainy season as well as drought during the dry season adversely affect stagnant or even reduce food production which is threatening productivity, stability as well as sustainability and equitability. Consequently, Indonesia as an agricultural country still depends on food stock from the international market, especially on import to meet the greater domestic demand on rice and wheat as well as soybean (Table 3 ). This current situation engages the food resilience to adapt amid of climate change not only based on cereals and grains, but also considering the role of root-crops especially cassava to be more prominently developed. Cassava development will not disturb and exaggerate the lowland which is used for cereal and grain crops, because the essential domain of cassava is in upland mainly. There are more than 25 million hectares of upland available and only 1,01 million ha or approximately $5.1 \%$ planted by cassava. Thus, there is an opportunity to expand cassava plantation in upland along with forest and other food crops, especially outside Java. Fallow and/ or bare land which is still under-utilized could be stipulated for agricultural development, with cassava as the base crop under a farming system. An advantage of cassava development in upland under agro-forestry was elucidated by Widodo (2012) that economic seduction is able to meet with ecological visualization especially the reduction of soil degradation. Moreover, poor farmers in upland are going to acquire cassava by implementing intercropping with cereals and grain

Indonesia with potential natural resources, inhabitants in villages

\begin{tabular}{|l|l|}
\hline Natural resource province district and village & Quantity \\
\hline Archipelago with the number of islands & 17,845 islands \\
\hline Marine area & $3,544,000 \mathrm{~km}^{2}$ \\
\hline Terrestrial area & $1,811,570 \mathrm{~km}^{2}$ \\
\hline Forest area & 139 million ha \\
\hline Plantation/estate crop area & 27 million ha \\
\hline Lowland & 8.4 million ha \\
\hline Dry upland & 25 million ha \\
\hline Population & $266,794,980$ people \\
\hline Population growth & $1.06 \%$ yearly \\
\hline Settlement \& infrastructure & 6.25 million ha \\
\hline The number of provinces & 34 provinces \\
\hline The number of districts and municipals & 416 districts and 98 municipals \\
\hline The number of villages & $83,184$ (74,754 villages $+8,430$ suburban $)$ \\
\hline
\end{tabular}

Source: Statistics Indonesia, (2018). 
Harvested area, productivity value and production of major food crops in Indonesia, 2017

\begin{tabular}{|l|l|l|l|r|l|}
\hline No & \multicolumn{1}{|c|}{$\begin{array}{c}\text { Food crop } \\
\text { commodities }\end{array}$} & $\begin{array}{c}\text { Harvested area } \\
(\mathrm{ha})\end{array}$ & $\begin{array}{c}\text { Productivity } \\
\left(\mathrm{t} \mathrm{ha}^{-1}\right)\end{array}$ & Value (Rp) & \multicolumn{1}{|c|}{ Production (t) } \\
\hline 1 & Rice & $13,203,643$ & 4.980 & $328,784,520,000,000$ & $65,756,904$ \\
\hline 2 & Maize & $3,864,692$ & 4.565 & $52,929,750,000,000$ & $17,643,250$ \\
\hline 3 & Soybean & 622,254 & 1.368 & $5,533,359,000,000$ & 851,286 \\
\hline 4 & Peanut & 539,459 & 1.281 & $3,456,455,000,000$ & 691,289 \\
\hline 5 & Mungbean & 297,315 & 1.148 & $2,389,394,000,000$ & 341,342 \\
\hline 6 & Cassava & $1,184,696$ & 20.296 & $24,044,025,000,000$ & $24,044,025$ \\
\hline 7 & Sweet potato & 178,121 & 12.329 & $3,294,049,500,000$ & $2,196,033$ \\
\hline
\end{tabular}

Source: Statistics Indonesia, (2018). Note: 1 USD = Rp 13,995 at Bank of Indonesia.

legumes. Howver, in the North Sumatra intercropping of cassava especially with maize and peanut was able to reduce from weed.

\section{Cassava Grafting Increased Yield}

Indeed cassava is not a native Indonesian crop; it was introduced from tropical Latin America around Brazil, Venezuela and Columbia. Cassava has been used as a source of food by Indian tribes since 5,000 BC. After Columbus discovered the new continent of America in 1492, cassava was recognized as a unique crop that produced a huge edible portion. The introduction of cassava into Indonesia was done in the middle of the $16^{\text {th }}$ century entering through Maluku (Cock, 1985). From Maluku cassava was distributed around the island of Indonesia and Philippines, including Java. During the Mataram Kingdom cassava was propagated in Pogung Raharjo in Sleman Yogyakarta and distributed throughout the island (1880-1920); therefore, in East Java cassava is also well known named as Pogung. In the early $20^{\text {th }}$ century, cassava was initiated for a large scale cultivation designated for export in the form of dried peel (gaplek) for animal feed to Europe by the Dutch government in Indonesia. There was introduction of cassava to Malaysia till India was undertaken by British from Java during Dutch under sub-ordination of the United Kingdom in the $19^{\text {th }}$ century. During the First World War and after that period, cassava saved people of Java from hunger especially those who lived nearby cassava plantation. Departing from that experience in the middle of the $20^{\text {th }}$ century, cultivation of cassava in Java was progressively developed with orientation to food, starch industry and export destination. From the beginning of the $20^{\text {th }}$ century (1905) in line with the first transmigration program, cassava was distributed in 105 households from Central Java to Lampung Sumatera. Furthermore, in conjunction with the transmigration program, cassava that recognized better adaptability under various suboptimal conditions was distributed throughout the country from Java (Widodo, 1986; Widodo, 2010; Widodo, 2011; Widodo, 2012). It was also shipped to Thailand during the King of Chulalongkorn (Rama V) after his visit to Java in $1938 / 39$. From Thailand cassava was then distributed to Cambodia, Laos, Vietnam and China. Its distribution continued during and after the Second World War as well. The progressive development of cassava in China from Hainan Island to the main land indicates that cassava is also able to adapt into a subtropical region. Although in the early distribution cassava was grown only across the longitude at the latitude around $10^{\circ}$ North and South Latitudes (Veltkamp \& de Bruijn, 1996), recently it is possible to grow cassava in $21^{\circ}$ North or South Latitude.

During the early freedom era till the middle of fifties (1945-1955) again the advantage of cassava was its ability to reduce the severe hunger due to post Second World War and internal conflict war which was caused by an unstable political situation. Since cassava was frequently saving people from hunger, and flexibility of storage in the form of dried and peeled roots, inspired and triggered Mukibat a farmer in Ngadiluwih Kediri to improve the productivity by trying to make the grafting union between ordinary cassava (Manihot esculenta) and perennial cassava (Manihot glasiovii). In the beginning, the grafting method of cassava was intended to avert stealing due to food insufficiency. After the harvest of cassava grafting method, Mukibat and family were very surprised due to unpredictable yield augmentation 5-10 fold compared to ordinary cassava. Immediately Mukibat method was announced and disseminated thereafter. In early sixties (1960-1969) and at the end of that decade, Mukibat method was very popular way to produce more food from starchy root of cassava in order to tame hunger (Widodo, 1986; 
Widodo, 2010). In line with the green revolution of cereal by introducing early maturing of newly rice varieties, cassava Mukibat system was able to provide adequate food significantly. By intensive management cassava Mukibat system in home garden is able to produce $>50 \mathrm{~kg}$ /individual plant/year. In addition, by implementing Mukibat system cassava in home garden could be harvested by peace-meal, thus cassava could be harvested in a longer period ( $>2$ years). Unlike ordinary cassava that mostly had to be harvested during the end of dry season and then processed as dried form to be stored, due to Mukibat method, cassava was always kept in a fresh form in the field and harvested when required (Widodo, 2010). Widodo et al. (2014) and Widodo, Wahyuningsih, \& Newby (2015) reported that cassava planted area (significantly decreased due to conversion of dry land as cassava domain shifted into irrigation area designated for rice lowland. Consequently, to maintain the supply of the demand that tends to increase, cassava development region was moved into a dry marginal risk prone area. Around seventies, the expansion of cassava outside Java progressively developed, especially in order to meet the high growth of demand for starch industry. Entering the third millennium, the demand of cassava tends to increase, although the additional of harvested area tends to stagnate or even decline. Recently, due to the shortage of availability and incredible price of fossil fuel, it is promoted to use cassava as raw material for bio-fuel (ethanol) that is considered to be more ecologically friendly and potentially renewable (sustainable). Therefore, the productivity level of cassava as well as expansion into appropriate domain (harvest area) is urgently required. Significant increase in productivity and harvest area simultaneously contribute to boost production nationally. Thus, there is no conflict to cover the demand of food, feed, existing industries as well as for bio-fuel.

\section{Food for All}

Although in the beginning of cassava cultivation from Maluku to Java was prioritized for plantation to meet the demand of feedstuff in Europe; however, due to food scarcity which was the chronic problem in that period, poor farmers in Java used cassava as the source of food (mainly carbohydrate). Plantation of cassava during Dutch occupation was emphasized to use the bitter cassava with HCN content $>100$ ppm. Rosling (1994), White, McMahon, \& Sayre (1994) and Delange, Ekpechi, \& Rosling (1994) elucidated that the techniques to reduce $\mathrm{HCN}$ content in cassava for consumption was completely recognized. From the beginning the export of cassava to European market was aimed to fulfill the feed demand, so shipment in the form of dried (gaplek) one was considered sufficient. Processing cassava into gaplek was very simple by peeling the skin and making the size of flesh smaller to get it dry faster during the sun drying (Damardjati, Widowati, \& Suismono, 1996).

Import value of various food crops in the period 2013-2017 (in 000 USD)

Table 3

\begin{tabular}{|c|c|c|c|c|c|c|}
\hline \multirow{2}{*}{ No } & \multirow{2}{*}{$\begin{array}{l}\text { Food crop } \\
\text { commodities }\end{array}$} & \multicolumn{5}{|c|}{ Year } \\
\hline & & 2013 & 2014 & 2015 & 2016 & 2017 \\
\hline 1 & Rice & 132,621 & 464,392 & 123,771 & 107,943 & 360,785 \\
\hline 2 & Processed rice & 1,285 & 50 & 12 & 11 & 5 \\
\hline 3 & Wheat & 819,032 & $1,185,165$ & $1.981,757$ & $1,320,220$ & $1,429,356$ \\
\hline 4 & Wheat flour & 222,355 & 259,574 & 389,937 & 321,059 & 398,038 \\
\hline 5 & Maize & 277,498 & 151,613 & 87,395 & 77,841 & 369,077 \\
\hline 6 & Processed maize & 21,615 & 22,996 & 48,484 & 29,538 & 115,161 \\
\hline 7 & Peanut & 54,161 & 62,191 & 99,640 & 176,740 & 222,650 \\
\hline 8 & Processed peanut & 5,368 & 2,348 & 2,889 & 2,368 & 2,799 \\
\hline 9 & Soybean & 299,578 & 482,889 & 698,489 & 624,979 & 840,037 \\
\hline 10 & Processed soybean & 509,477 & 17,990 & 34,233 & 22,724 & 31,136 \\
\hline 11 & Sweet potato & 98 & 123 & 7 & 50 & 45 \\
\hline 12 & Cassava & 47 & 50 & 19 & 336 & 15 \\
\hline 13 & Cassava starch & 70,237 & 77,752 & 57,929 & 49,577 & 120,739 \\
\hline 14 & Other food crops & 155,084 & 1,969 & 2,413 & 4,476 & 3,997 \\
\hline
\end{tabular}

Source: Ministry of Agriculture, (2017). 
This simple way of preparation could be done directly by farmers. It seemed that the method to prepare gaplek was taught by Dutch to farmers in Java in order to fulfill market of gaplek in Europe. The existence of gaplek in farmers' circumstances who chronically suffered from food scarcity and with the richness of indigenous knowledge stimulated people to prepare palatable food from dirty raw material (during processing gaplek, after peeling, gaplek is sun dried directly onto soil). Unlike fresh cassava that easily deteriorates in 3-4 days, in a form of gaplek, cassava could be stored up to 12 months to secure against food insufficiency. From gaplek several food preparations could be generated. The most common food preparation from gaplek that is still practiced by rural household till recently is tiwul, as staple food other than rice for poor income communities. Tiwul can be processed from gaplek flour. Processing tiwul is as follows: flour of gaplek is mixed with hot water to form hand made granules, then the granules are steamed for approximately 15-20 minutes. Tiwul is the most popular staple food derived from gaplek which can be consumed directly after being cooked, or dried as a storable instant tiwul (Ginting \& Widodo, 2000). To eat tiwul in the same way as rice preparation, several side dishes could be used to meet the hedonic taste. Instant tiwul is popular food not only for the poor, but also for middle income communities.

In addition to tiwul, there is gatot that could be prepared from gaplek and its preparation is faster than tiwul. Gatot can be prepared by soaking gaplek into water $>6$ hours to make it soft, and then it is sliced into small pieces and steamed. Unlike tiwul as staple food, gatot is only used as additional food (snack) that is mostly eaten with shredded coconut. Indeed, tiwul also can be used as a snack, by mixing coconut sugar during preparation, and then it is mixed with shredded coconut to improve palatability for eating. Fermented food could also be generated not only from fresh cassava, but also from gaplek. However, the best quality of fermented food from cassava has originated from fresh cassava without any physical or microbial deterioration. On the contrary, gaplek during drying processed suffered from physical deterioration. Therefore, fermented products from gaplek are mostly unattractive compared to that from fresh cassava, especially in terms of color. The color of fermented fresh cassava can be white or yellow; it depends on the original color of flesh in the fresh form. But the color of fermented food from gaplek looks dirty, grey, brown to dark (blackish). The previous fact up to recent time revealed that the richness of food related products generated from fresh cassava as well as gaplek were a triggering factor to increase the progressive demand. Improvement of processing of traditional food as well as recent innovation for generating new products from cassava due to the price of cassava in the form of fresh gaplek is cheaper than that of other raw material of food processing, for instance, wheat, rice, maize etc. Processing of food from gaplek, modified cassava flour as well as from starch had been disseminated to many end-users, and the quality of materials was clearly recognized. Previous experience from starch extraction industry tended to build in huge scale that ultimately affected many problems, namely sustainability of raw material supply till pollution from waste to the environment. A small scale extraction of tapioca can be diluted into wider environtment; however, this is a temporary solution. So, there are many opportunities for rural

Cassava development progress in Indonesia during 50 years

Table 4

\begin{tabular}{|c|r|r|r|}
\hline Years & Harvest area (ha) & Productivity $\left(\mathrm{t} \mathrm{ha}^{-1}\right)$ & \multicolumn{1}{|c|}{ Production $(\mathrm{t})$} \\
\hline 1968 & $1,503.000$ & 7.56 & $11,356,000$ \\
\hline 1973 & $1,429.000$ & 7.80 & $11,186,000$ \\
\hline 1978 & $1,383.000$ & 9.30 & $12,902,000$ \\
\hline 1983 & $1,221.000$ & 9.90 & $12,100,000$ \\
\hline 1988 & $1,303.000$ & 11.87 & $15,471,000$ \\
\hline 1993 & $1,401.600$ & 12.30 & $17,285,400$ \\
\hline 1998 & $1,205.400$ & 12.20 & $14,696,200$ \\
\hline 2003 & $1,244.500$ & 14.90 & $18,523,800$ \\
\hline 2008 & $1,341,607$ & 15.50 & $20,794,607$ \\
\hline 2013 & $1,065,752$ & 22.46 & $23,936,921$ \\
\hline $2017 *$ & 904,359 & 22,48 & $20,330,000$ \\
\hline
\end{tabular}

Sources: Statistics of Indonesia, (2018) * FAO (2017). 
community to gain better income. Young cassava leaves can be eaten as vegetable, but the abundance of cassava leaves are mostly utilized as a source of green fodder for animal husbandry, such as goat, sheep, cow, and buffalo. There is a new potential to use cassava leaves for rearing the silk worm. Early work in around Surakarta which produces traditional Batik from silk, indicates that textile of silk generated from silk worm ransomed by cassava leaves is as good as the quality of the normal silk. It means that cassava leaves can be used to be converted to produce fiber by the merit of silk worm. Organic manure generated from cassava processing as well as from animal husbandry should be re-incorporated into the land to maintain better soil fertility. Under the agro-forestry system cassava is assumed as soil depleting crop; however, by proper crop arrangement as well as organic and inorganic fertilizers application, the long term soil fertility can be maintained and greener forest is also normally attained. In a natural forest, there is no input as well as cultural practices applied, meanwhile in agroforestry input in the form of fertilizers, etc. applied to cassava will also induce the growth of trees in the forest. Therefore, to allow cassava to enter among forest trees, a space or distance from trees should be arranged 3-6 m.

\section{Phylanthropy to End Hunger and Poverty}

In Indonesia, the overall reformation is being carried out for 20 years; however, the progress is not as expected by many people. Reverie for the democratization was mis-interpreted by most people to squat the forest area that was ultimately promoted to the worse climate (weather) condition. Massive handling in development planning fastened the conversion of agricultural land into non-agricultural purposes. There is a significant trend that land tenure becomes narrow, especially in densely populated areas such as Java. Due to trade liberalization, poor farmers, who grow cassava, experience worse conditions. The abundance of food and other agricultural produce from abroad hits the price of cassava under poor conditions (Widodo et al., 2014; Widodo, Wahyuningsih, \& Newby, 2015). On the other hand, there was no government endeavor to support cassava farmers to gain better incentives. The quality of newly released cultivars, which are expected as a significant incentive and are able to increase productivity, is not as good as of local cultivars; thus, the income generated from the use of new cultivars was not better. It means that implementation of new cultivars as a tool for philanthropic investment to eradicate poverty is not simple; integration efforts to generate income for the poor by adopting new cultivars (Sundari et al., 2000) are required. Product development is considered as an appropriate way out to help cassava farmers to use new high yielding cultivars (Antarlina \& Harnowo, 1992; Blanshard et al., 1994; Bokanga et al. 1990; Bradbury, 1990). To end this kind of poverty under such circumstances requires philanthropic effort which is not instantly meant to generate income promptly. In attempts to create the new high yielding cultivars of cassava requires at least 5-6 years from pollination $\rightarrow$ seed production $\rightarrow$ germination $\rightarrow$ single plant selection $\rightarrow$ single row selection $\rightarrow$ single plot selection $\rightarrow$ replication trials $\rightarrow$ multi-location trials $\rightarrow$ new release cultivars. To perform better than its biological potential, the newly introduced cultivars need an input of organic and inorganic fertilizers in agronomic practices, assisted by protecting them from pest-disease and weed interference without neglecting ecologically friendly principles. Post harvest handling and processing of cassava into various products should be followed by the market trends (Lynam, 1994; Nambisan \& Sundaresan, 1985; Nweke \& Bokanga, 1994)

In fact, domestic and global market of cassava indicates progressive growth. So, there is no reason to inhibit fair trade process. Philanthropic work is required to observe the process fairly, especially value chain stakeholders. Incubation of humanity business on cassava based by funding from charity revolving funds will provide a worthy prototype. Continuation of prototype into larger scale by their own hand of the community to attain sustainability also needs monitoring and evaluation.

Unity of philanthropic actions to prepare more civilized livelihood is urgently required. Philanthropic works hence are mostly undertaken individually or segmented to certain alliance such as a group of religions, political parties, and government institutions as well as from private companies. Indeed, if those of charity actions could be unified into the clear continuum, the first and top priority of the SDGs is not too difficult to be gradually attained. The collected fund can be allocated for executing several programs, including food program and covering cassava. The implementation of philanthropy into cassava development means to increase productivity with simultaneously eradicated poverty by triggering distribution of new high yielding cultivars, providing information on the better cultural practices, establishing clusters for processing and marketing (Widodo, 2010). In rural community, there is definitely a wide opportunity for charity to produce more food, because many poor people are still awaiting food aid due to unstable political situation, drought and/ or flood and ecological calamities, climate change as well as pest, disease, weed and other biotic stresses. During flooding a five-day distribution of food free of 
charge is recommended at every household as well as in the poor communities. Food produced from charity work such as cassava in the forms of noodle, bread, cookies etc. are adequately worthy to be distributed for supporting this program. In the frame of the charity program, the price of cassava fresh tuber in a village can be maintained better Rp 1,370/kg (1 USD $=\mathrm{Rp} 13,700)$, which does not fall into a low price. As the government has aligned the price of cassava and it is almost stable, farmers will not be confused.

\section{Conclussions}

1. Cassava as an ancient crop can be developed by increasing productivity to meet new hope for reducing hunger and alleviating poverty in rural areas of Indonesia as the first priority of SDGs.

2. To support cassava development, philanthropic work in the form of revolving fund is suggested, so many poor communities will acquire a benefit to escape from poverty and to end hunger.

3. The role of the government to control the price of cassava has to be stipulated; the floor price to protect farmers who grow cassava as well as the ceiling price for protecting the sustainability of industries should be set.

4. Food produce in the form of noodles, cakes, cookies, bread, etc. from cassava in the frame of philanthropic actions can be distributed to the social safety net as free meals as well as it should be delivered to the poor communities who require food support.

\section{References}

1. Antarlina, S.S., Harnowo, D. (1992). Identification of cassava processing. A progess report of research activity funded by APBN 1991/1992. MARIF. Malang. 15 p.

2. Blanshard, A.F.J., Dahniya, M.T., \& Poulter, N.H., Taylor, A.J. (1994). Fermentation of cassava into Foofoo: Effect of time and temperature on processing and storage quality. J. Sci. Food Agric. 66(4):485-492.

3. Bokanga, M., O'Hair, S.K., \& Narayanan, K.R. and Steinkraus, K.H. (1990). Cyanide detoxification and nutritional changes during cassava (Manihot esculenta Crantz) fermentation. In R.H. Howeler (ed). Proceedings of the $8^{\text {th }}$ Symposium of the International Society for Tropical Root Crops. Bangkok, Oct 30 - Nov 5, 1988. CIAT- CIP. p. 385-391.

4. Bradbury, J.H. (1990). Cyanide in cassava and acridity in edible aroids. In R.H. Howeler (ed). Proceedings of the $8^{\text {th }}$ Symposium of the International Society for Tropical Root Crops. Bangkok, Oct 30 - Nov 5, 1988. CIAT- CIP. p. 171-178.

5. Cock, J.H. (1985). Cassava: New potential for a neglected crop. International Agricultural Development Service. Westview Press Inc., Boulder USA and London UK. 191 p.

6. Damardjati, D.S., Widowati, S. \& Suismono, S. (1996). Development system of cassava flour agro industry in Indonesia. In M. Syam, Hermanto and A. Musaddad (eds). Performances of Food Crop Research. Book 4. CRIFC, Bogor. p. 1212-1221.

7. Delange, F., Ekpechi, L. \& Rosling, H. (1994). Cassava cyanogenesis and iodine deficiency disorders. Acta Horticulturae (375):289-293.

8. FAO. (2017). Crop Prospect and Food Situations. Food and Agriculture Organization. No 2 November 2017. Retrieved in February 26, 2018, from www.fao.org.

9. Ginting, E. Y., Widodo, Y. (2000). Koes Hartoyo dan N. Saleh, (2006). Kesesuaian klon-klon ubikayu untuk bahan baku bio-etanol (Suitability of cassava clones as raw material for bioethanol). Laporan Tahunan Balitkabi Tahun 2006. 24 p.

10. Lynam, J. (1994). Cassava safety and development. Acta Horticulturae (375):361-371.

11. Nambisan, B., Sundaresan, S. (1985). Effect of processing on the cyanoglucoside content of cassava. J. Sci. Food Agric. 36 (11):1197-1203.

12. Nweke, F.I., Bokanga, M. (1994). Importance of cassava processing for production in SubSaharan Africa. Acta Horticulturae (375):401412.

13. Ministry of Agriculture (Kementerian Pertanian), (2017). Statistik Pertanian Indonesia (Agricultural Statistic of Indonesia). Pusat Data dan Sistem Informasi Pertanian. Kementerian Pertanian. Jakarta. 303 p.

14. Ohlhorst, S., W. Fisher, K., \& Anderson, K. Glasener, L. Randel, K., Mowrer, , Gullifort, J.. (2012). Food Nutrition Agriculture and Natural Resource Sciences in the FY 2013 Budget. United State Department of Agriculture (USDA) National Institute of Food and Agriculture (NIFA). Pp 269-277.

15. Rosling, H. (1994). Measuring effects in humans of dietary cyanide exposure from cassava. Acta Horticulturae (375):271-283.

16. Sawit, M.H. (2002). Beras untuk keluarga miskin (RASKIN): sebuah program perlindungan sosial. (Rice for the poor: a program for protecting 
social). Majalah Pangan Media Komunikasi dan Informasi Nomor 38 (XI):10-19.

17. Saifullah, A. 2002. Badan penyangga kebijaksanaan pasar hasil-hasil pertanian dalam usaha menciptakan ketahanan pangan. (Buffering agent for market policy of agricultural products in the effort of food security). Majalah Pangan Media Komunikasi dan Informasi Nomor 38 (XI):30-40.

18. Simatupang, P., Fleming, E. (2001). Food Security Conditions and Problems in South Pacific Island Countries. Palawija News 18(2):516.

19. Statistics Indonesia (2018). Statistics Indonesia. Badan Pusat Statistik. www.bps.go.id.statistics indonesia.

20. Sundari, T., Hartojo, K., \& Sholihin and Ginting, E. (2000). Identification and characterization of cassava clones for good taste purposes. In A.A. Rahmiana, J. Soejitno, D.M. Arsyad, Heriyanto, Sudaryono, Suharsono and I.K. Tastra (eds). Source Management of Legume and Tuber Crops. CRIFC. Bogor. p.217-223.

21. Veltkamp, H.J., de Bruijn, G.H. (1996). Manihot essculenta Crantz. In M. Flach and F. Rumawas (Eds.) Plant Resources of South East Asia No 9. Plant yielding non seed carbohydrates. Pp 107113.

22. White, W.L.B., McMahon, J.M. \& Sayre, R.T. (1994). Regulation of cyanogenesis in cassava. Acta Horticulturae (375):69-77.

23. Widodo, Y. (1986). Pola pengembangan agroindustri ubikayu di Indonesia (Development pattern of cassava agro-industry in Indonesia). Jurnal Litbang Pertanian V (3): 67-72.

24. Widodo, Y. (2010). Harmonizing the supply of cassava to meet the increasing demand for food and various other uses in Indonesia. In R.H. Howeler (Ed.) A New Future for Cassava in Asia: its use as food, feed and fuel to benefit the poor. Proc. Of the $8^{\text {th }}$ Regional Workshop held in Vientiane, Lao PDR, Oct 20-24, 2008. NAFRIThe Nippon Foundation-CIAT. Pp79-99.

25. Widodo, Y. (2011). Strategi Sinergistik Peningkatan Produksi Pangan dalam Hutan Lestari Melalui Wanatani (Synergistic strategy for increasing food crops under forest sustainability by agro-forestry). PANGAN Media Informasi dan Komunikasi BULOG Vol 20(3):251-268.

26. Widodo, Y. (2012). Food from the forest of Java: tropical agro-forestry experiences in feeding dwellers and keeping the environment greener. In C.A, Brebbia (Ed.) SUSTAINABILITY TODAY. Wessex Institute of Technology (WIT) Press, Southampton, Boston. Printed in UK. Pp 281-293.

27. Widodo, Y., Rahayuningsih, St. A., \& Saleh, N., Wahyuningsih, S. (2014). Incorporating Root Crops under Agroforestry as the Newly Potencial Source of Food Feed and Renewable Energy. Int. Journal of Renewable Energy Development 3(3)2014:193-206.

28. Widodo, Y., Wahyuningsih S., \& Newby, J. (2015). Fuelling Cassava Development to Meet the Greater Demand for Food and Bio-fuel in Indonesia at Energy Procedia 65(2015) 386-394. 